\title{
AN INDONESIAN SCULPTURE IN \\ THE KRÖLLER-MÜLLER MUSEUM ${ }^{1}$
}

\section{Introduction}

In 1919 Helene Kröller-Müller acquired an Indonesian sculpture from Frederik Muller \& Cie, a well-known auction house in Amsterdam at the time (Pl. 1). The inventory of the auction - which took place on 25-28 November 1919 - listed the sculpture under lot numbers 1548-1567, together with 19 other sculptures from the Netherlands Indies: 'Collection de vingt sculptures en grès, d'idoles, etc. des Indes néerlandaises. (Boroboudour, Java?). - Par pièce'. ${ }^{2}$

Helene Kröller-Müller was born in Essen in Germany in 1869. In 1888 she married Anton Kröller, a promising employee at the Rotterdam branch of her father's firm Wm H. Müller \& Co. A year later he was to become the director of this firm and one of the richest business men in the Netherlands. In 1907 Helene began to collect art, mainly the contemporary art of which Van Gogh was her favourite, but also non-western art. ${ }^{3}$ When she bought the Indonesian sculpture in 1919 she was making plans to build a museum for her growing art collection. Because of long discussions with architects and financial problems of the Müller firm in the 1930s it was not until 1938 that her dream came true and the Kröller-Müller Museum came into existence thanks to an initiative of the Dutch state. ${ }^{4}$ Helene Kröller-Müller was to be the first director, but not for long as she died in 1939.

The sculpture she acquired in 1919 is the only Indonesian piece in the Kröller-Müller Museum collection. ${ }^{5}$ It is registered as KM 113.611 but the inventory file gives little information about the identification of the depicted figure ('Hindu-Buddhist dwarf figure'), the origin of the relief ('Indonesia'), or its date ('unknown'). In this article I wish to establish its original context.

\section{Identification}

The sculpture is a relief on a square slab of stone that depicts a dwarf-like figure squatting on its haunches (Pl. 1). The figure's arms rest on its knees and the hands are raised as if to support the top part of the stone. The figure has curly hair and wears jewellery (large round ear rings, a necklace, anklets, and armlets) but no clothes. It sits on three round objects that represent its genitals. It holds the two ends of a sash in its upraised hands while the middle part of the sash is wrapped around the front of its fat belly. Plant-like

PI. I.

An Indonesian sculpture in the Kroller-Muller Museum, Otterlo, The Netherlands ornamentation fills the spaces on both sides of the dwarf-like figure. There are plain borders on the left, the top and the bottom of the panel but on the right such a border is missing. 


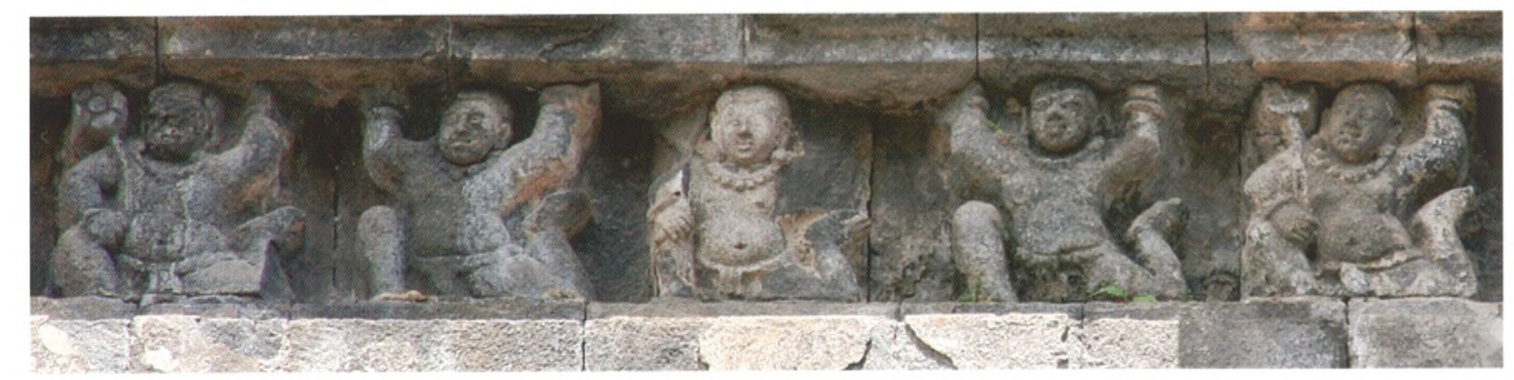

PI. 2.

Frieze with flying dwarflike carrier figures, Candi Kalasan
Similar dwarf-like figures abound in the Hindu and Buddhist temple art of Central Java. Like many other ornaments carved on temples - such as monster heads, garlands, wishing trees, and vases of plenty - they derive from Indian art. Van Erp uses the term atlantes to denote such figures on Borobudur, ${ }^{6}$ but more often the Sanskrit word gana is used. ${ }^{7}$. Ganas are the dwarf-like followers of the Hindu god Siva and his son Ganesha, whose name means 'Lord of the ganas'. ${ }^{8}$ However, since the dwarf-like figures are found on both Hindu and Buddhist temples in Central Java, it is questionable whether gana, specifically associated with Siva, is the correct term. More semi-divine dwarf-like or burden-bearing creatures such as guhyakas, yaksas, and naras are known in Sanskrit literature. ${ }^{9}$ It is difficult to decide which term would best fit the figures portrayed in Central Javanese art.

These figures can be found on many of the surviving temples (candi) in Central Java, for instance Banyunibo, Barong, Borobudur, Dieng Candi A, Gedong Songo I, Kalasan, Kedulan, Loro Jonggrang, Lumbung, ${ }^{10}$ Mendut, Merak, Morangan, Pendem, Plaosan Lor, Sambisari, Sari, Sewu, and Sojiwan. They are seen at various locations, often integrated into an element with a support function, for instance in friezes (Pl. 2), at the top of pilasters (Pl. 3), at the bases of doorways or niche posts, or on panels below niches (Pl. 11).

The dwarf-like figures display various forms. When they are found high up on a temple, as for example at Candi Kalasan (Pl. 2), they are often depicted in a flying attitude with one leg bent in front and the other leg bent backwards. Most examples appear in a squatting attitude with their hands uplifted as if carrying something (Pls 3-7, 9). Some examples, for instance at Candi Sojiwan (Pl. 9), are seated on a lion or an elephant. Others, such as those at Candi Kalasan, have only one hand raised in a lifting position (Pl. 2). Those that have both hands raised show various hand positions: both hands turned outward seems to be the most common position (Pls 3 and 6); whereas both hands turned inward is the most common at Candi Sewu (Pl. 4); one hand turned inward and the other turned outward is found at Candi Gedong Songo I, Candi Kedulan, Candi Pendem (Pl. 5), and Candi Plaosan Lor; and both hands turned to the front is the common way of depiction at Candi Loro Jonggrang (Pl. 7). Usually a piece of cloth hides the dwarfs' genitals as can be seen in an example from Candi Sambisari (Pl 6 ), but sometimes the genitals: 39am are visible as can be seen on the figures at Candi Mendut (Pl. 3). Sometimes ${ }^{\text {ccess }}$ 


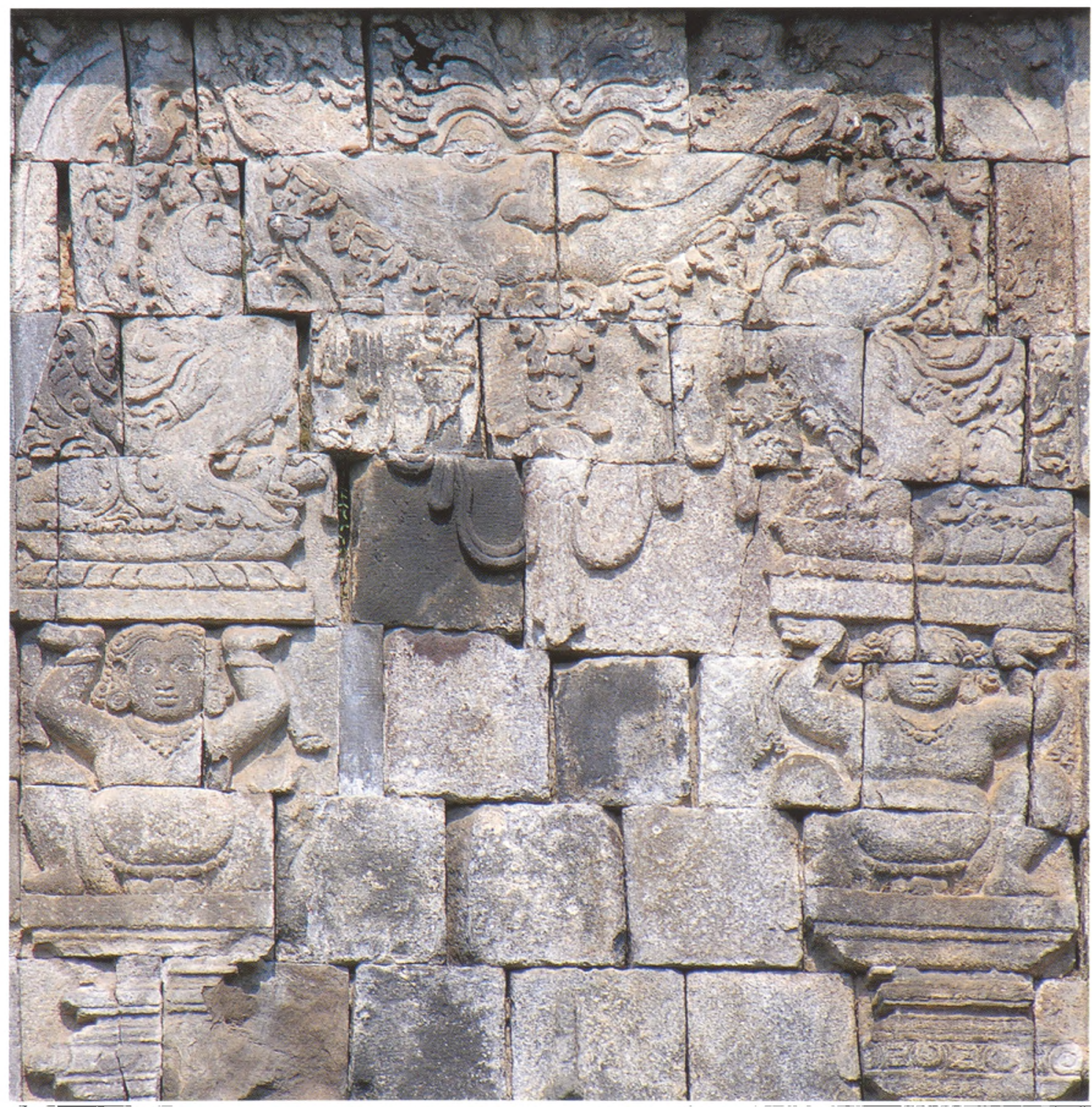

PI. 3.

Pot-bellied dwarf-like figures at the top of pilasters carrying a kalamakara arch the dwarf-like figures are shown carrying a flower (Pl. 2), a flywhisk (Pl. 9), bells (Pls 5 and 6), or frond-like vegetation. They are occasionally found in association with plant-like ornaments, as on Candi Lumbung (Pl. 8).

\section{Origin}

By comparing the variety of dwarf-like figures found at several Central Javanese temples, it is possible to conclude that the Kröller-Müller sculpture has originated from the Barong temple complex.

Candi Barong is situated in the hamlet Candisari in the village Sambirejo, Prambanan district, Sleman regency, Special Region (Daerah Istimewa) Yogyakarta, not far from Prambanan, a smale town on the road from 2023 o2: 29:39 AM Yogyakarta to Surakarta. A small path leads up a hill on which the temple 


\section{6}

PI. 4. >

Dwarf-like figure, Candi Sewu

PI. 5. \>

Dwarf-like figure, Candi

Pendem

PI. 6. >

Dwarf-like figure, Candi Sambisari

PI. 7. >>

Dwarf-like figure, Candi Loro Jonggrang
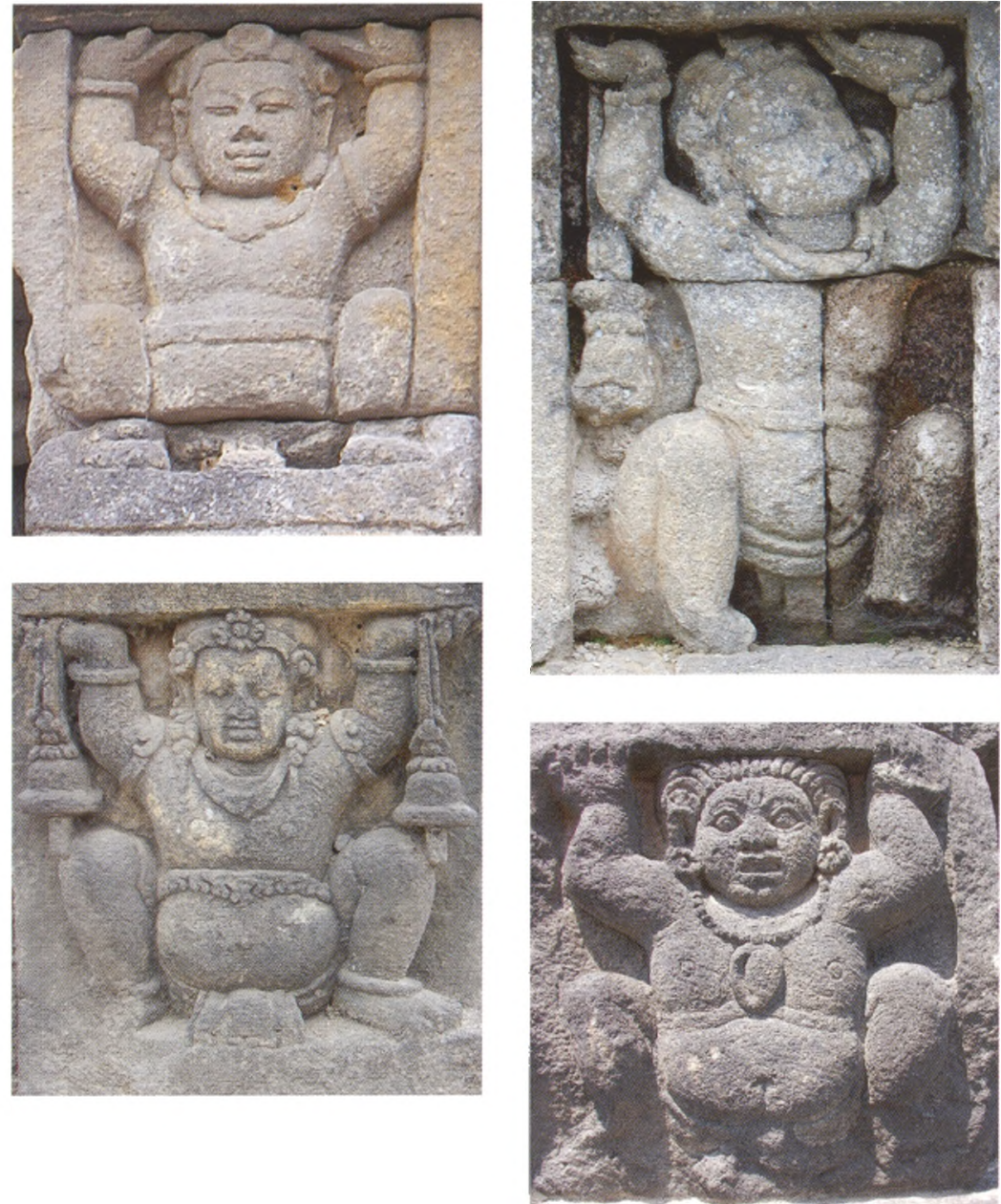

complex was built. From the top of the hill there is a spectacular view across the landscape to the southwest.

Candi Barong is a relatively new name for this temple complex. When Helene Kröller-Müller bought her Indonesian sculpture, the site was called Candi Sari or Sari Sorogedug (to distinguish it from another Candi Sari, near Kalasan). In his Inleiding tot de Hindoe-Javaansche kunst N.J. Krom mentions that this temple had completely disappeared. ${ }^{11}$ It must have been in this condition for some time and was probably one of the sites which J.W. IJzerman - who made a survey of this area at the end of the $19^{\text {th }}$ century - described as 'jammerlijke puinhopen, gesloopt door een verbasterd nageslacht, dat niet in staat is de grootheid zijner vaderen te waarderen' ${ }^{12} .{ }^{13}$ Not only did local people use the temple stones to build their own homes, attractive pieces could be taken unnoticed to add to a private collection or to sell on the art market. This was probably the fate of the sculpture in the Kröller-Müller Museum.

The situation described by IJzerman has changed completely. Indonesians are well aware of their cultural heritage The Barong temple complex thas $_{2: 29: 39 \mathrm{Am}}$ restored between 1984 and 1991 and is no longer a pile of rubble, unworthyccess 
PI. 8.

Dwarf-like figure in the centre of a spiral ornament, Candi Lumbung

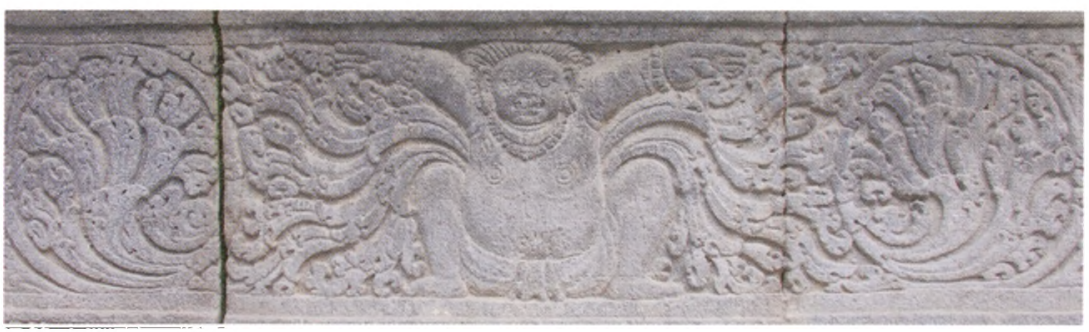

of a visit (Pl. 11). ${ }^{14}$ Even in far away Kalimantan, the Banjarmasin Post of 21 August 2003 devoted an article to 'the amazing Candi Barong', urging visitors going to Prambanan to make the effort to visit nearby Candi Barong and enjoy its breathtaking panoramic views.

The Barong temple complex consists of two courtyards built on terraces on the hill. On the lower terrace only the foundations of a number of buildings can be seen. The upper terrace, which one enters through a gateway in its western wall, contains two temples standing next to each other on a northsouth axis. They are called Candi I and Candi II, but since there is confusion in the literature about which is which I prefer to designate them as the northern and southern temples. ${ }^{15}$ The two buildings are very similar. They are both small square temples measuring $8.40 \times 8.40 \mathrm{~m}$ at their base. ${ }^{16}$ They are unique because, unlike other Central Javanese temples, their inner spaces - where one would normally find a temple chamber containing a central image - are enclosed on four sides and do not have entrances. All four sides have niches while other temples have niches in three sides and a staircase leading to the entrance on the fourth side. All the niches in the two Barong temples are empty now. Of the six images that were found at the site, only one bears clearly distinguishable attributes. It is a four-armed female deity who carries a flower and a rice ear in her upper hands. ${ }^{17}$ The latter attribute is unknown in Indian iconography, but since rice is still associated with
PI. 9.

Dwarf-like figures seated on lions and an elephant, Candi Sojiwan

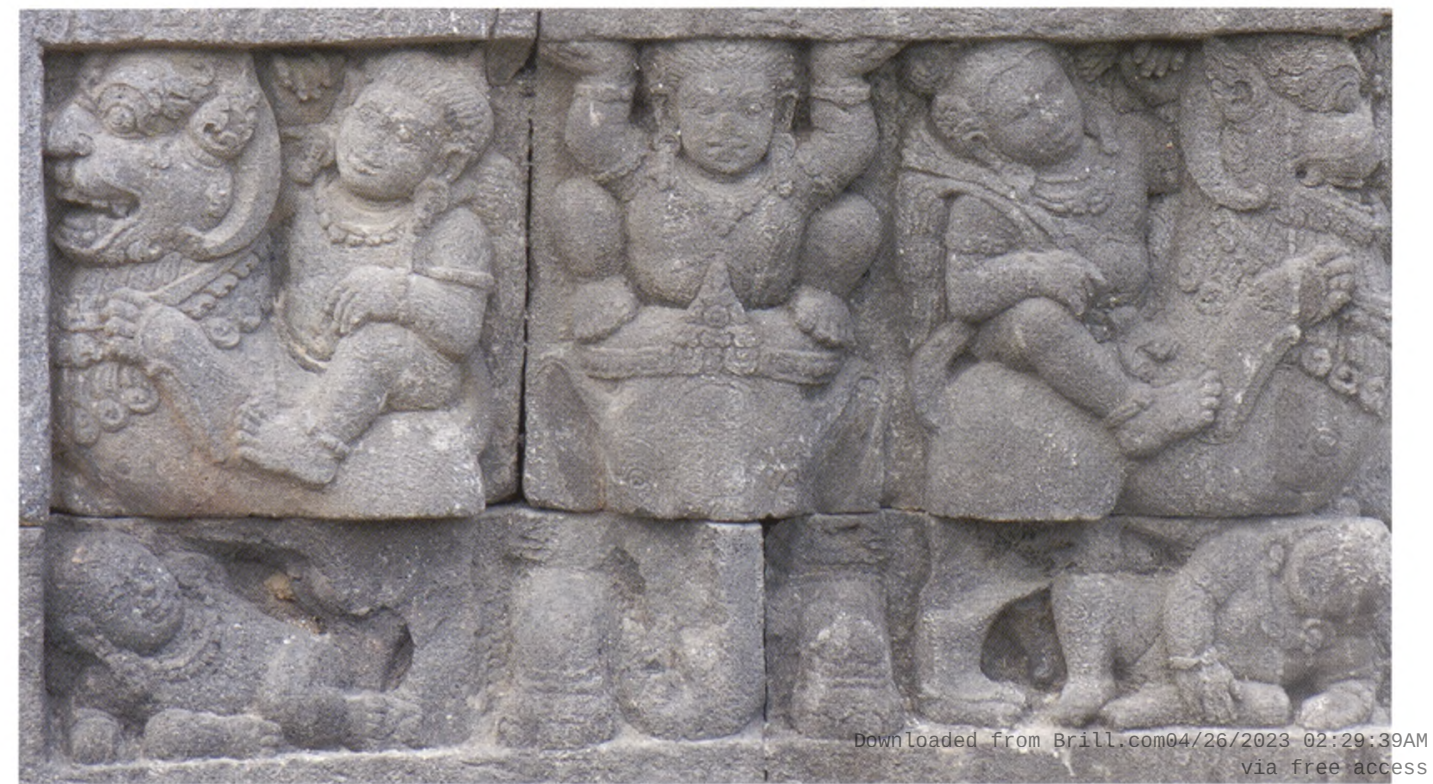




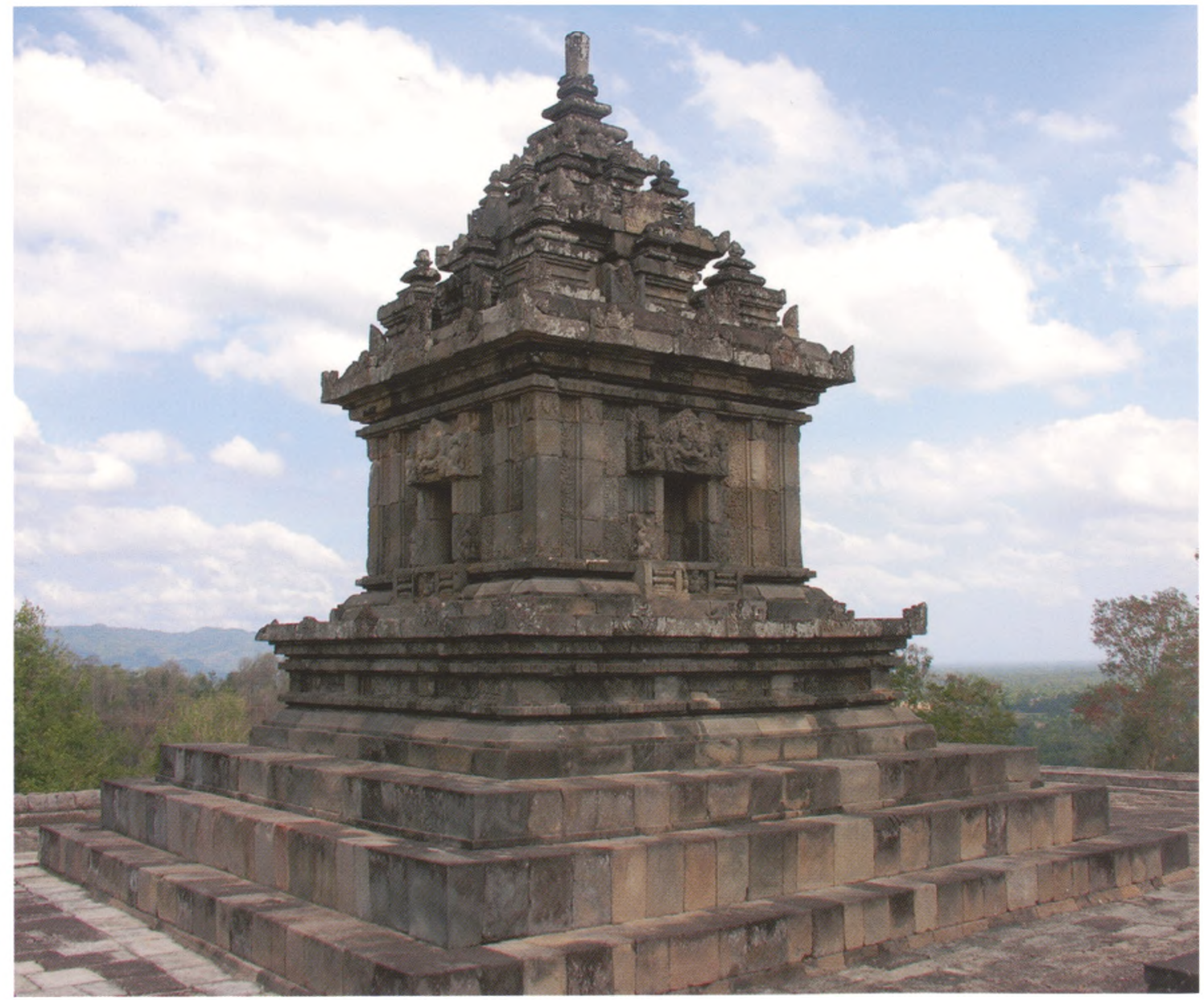

PI. 10.

Candi Barong, the southern temple, north eastern corner

PI. 11. \>

Candi Barong, the northern temple, north wall
Dewi Sri in Indonesia, female images from Hindu-Buddhist times that carry a rice ear have been identified as representing the goddess Sri, who, according to Indian mythology, is one of the god Visnu's wives. Furthermore, an image of Ganesha, god Siva's son, has been found in the immediate vicinity, so that a Hindu affiliation, therefore, seems most likely.

The ornamentation of the two temples looks very similar apart from some minor details. A kala (monster head) and two outward facing makaras (fabulous animals with elephants' trunks) crown the niches at the centre of each of the four walls (Pl. 11). At the bottom of the niche surrounds we find two more outward-facing makaras. The niche supports consist of two baluster ornaments and a dwarf-like figure in between. The wall surfaces on either side of the niches are decorated with diaper patterns and spiral ornaments (Pl. 14). One of the clearly observable differences in the ornamentation of the two temples is that the kalas of the northern temple have a curved outline, while those of the southern temple have a sharp-pointed outline (compare 29:39 AM Pls 11 and 14). 


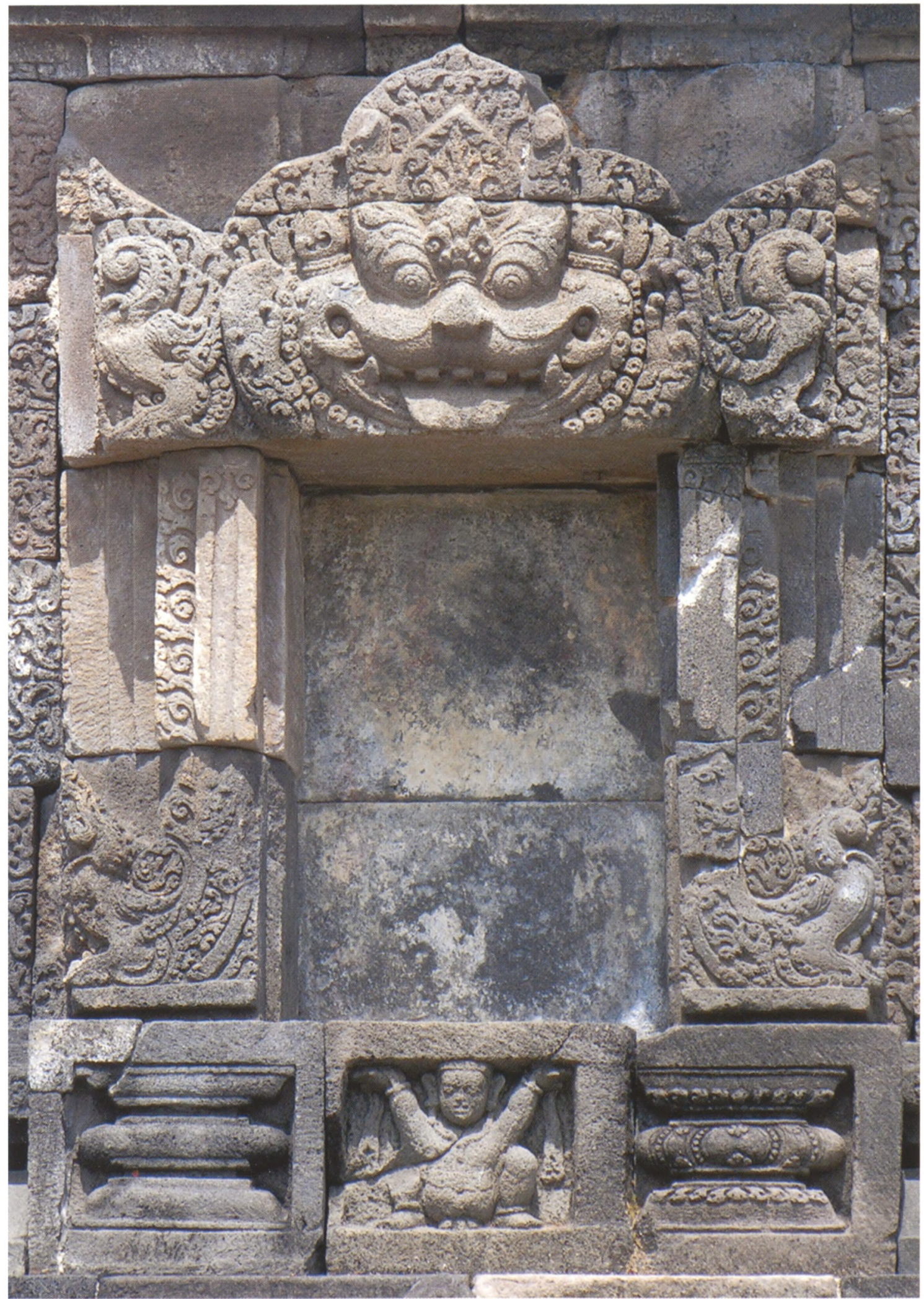


PI. 12.

Candi Barong, dwarflike figure on the west wall of the northern temple
The buildings at Candi Barong are the only temples with dwarf-like figures that are positioned against a background of foliate ornament in a similar manner to the Kröller-Müller sculpture. There are also some other aspects in which the dwarf-like figures of Candi Barong resemble the Kröller-Müller sculpture: they do not wear a piece of cloth in front of their genitals and they hold the ends of a sash in their uplifted hands while the middle section of the sash is wrapped around the front of their bellies. Holding a sash in this manner is characteristic for the dwarf-like figures at Candi Barong and is not found on any other temple. The faces of the various Barong sculptures are slightly different. One example has straight hair which falls across the forehead ending in curls (PI. 13); another seems to be wearing a head band made of flowers and leaves (PI. 12), while another has large elephant-like ears (Pl. 11). The hand positions of the figures differ in the northern and southern temples. In the northern temple the figures have hands that turn outward (PIs 11 and 12), while in the southern temple the figures have hands that turn forward in a similar fashion to the figures at the Loro Jonggrang temple complex (Pl. 13). Since the Kröller-Müller figure also has its hands turned forward it seems likely to have originated from the southern temple. It could well have decorated the western wall because there a section of the ornamentation below the niche, where the other niches have a dwarf-like figure, is missing (Pl. 14). The panel with the baluster ornament that is still in situ has a plain border on the left side. This matches exactly with the missing panel border on the right side of the Kröller-Müller piece.

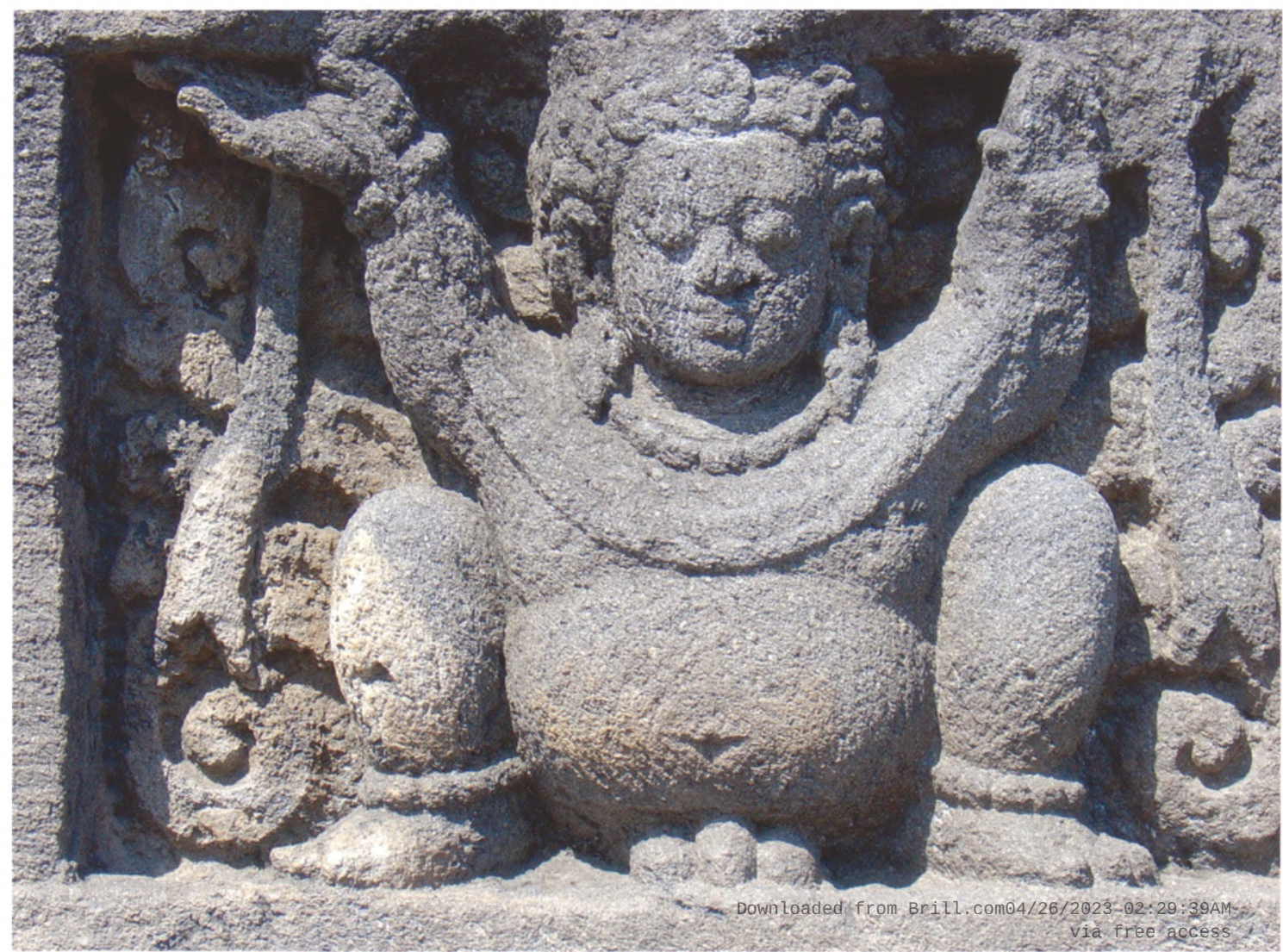


Central Java enters history in AD 732 with the inscription of Canggal, the earliest dated Central Javanese inscription. The inscription of Wulakan, which carries a date corresponding to $\mathrm{AD} 928$, marks the end of the Central Javanese period. These two dates roughly delineate the Central Javanese period. Almost all dated inscriptions found in Central Java fall within this period. Only very few are of a later date. The majority of the later inscriptions have been found in East Java and belong to the East Javanese period (AD 929-c.1500).

Central Javanese inscriptions contain valuable information about economic and social developments but little information about the temples. They remain silent about the builders of the temples, the use of the temples, and their dates. The various chronologies proposed for the temples have been based on a variety of other sources and interpretations of historical developments in Central Java between 732 and 928: dated inscriptions associated with a temple or found in its neighbourhood, the palaeography of undated inscriptions on the temples, the development of building techniques, and/or the formal and stylistic development of architectural elements or sculptural ornamentation.

PI. 13.

Candi Barong, dwarflike figure on the north wall of the southern temple
It is generally believed that none of the architectural remains from Central Java post-date the year 928. Previous researchers, like N.J. Krom, assumed that building activities continued until the end of the Central Javanese period.

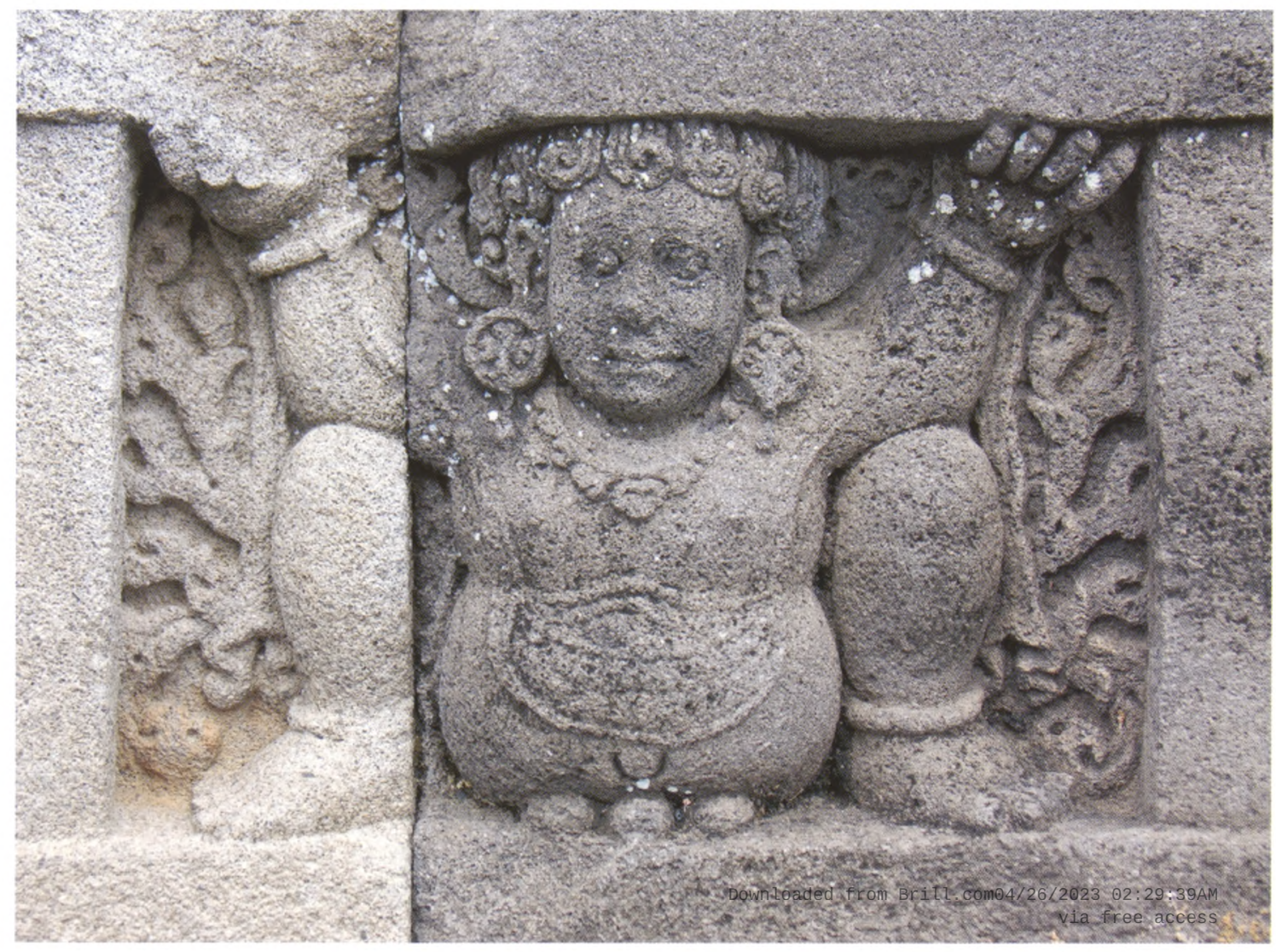




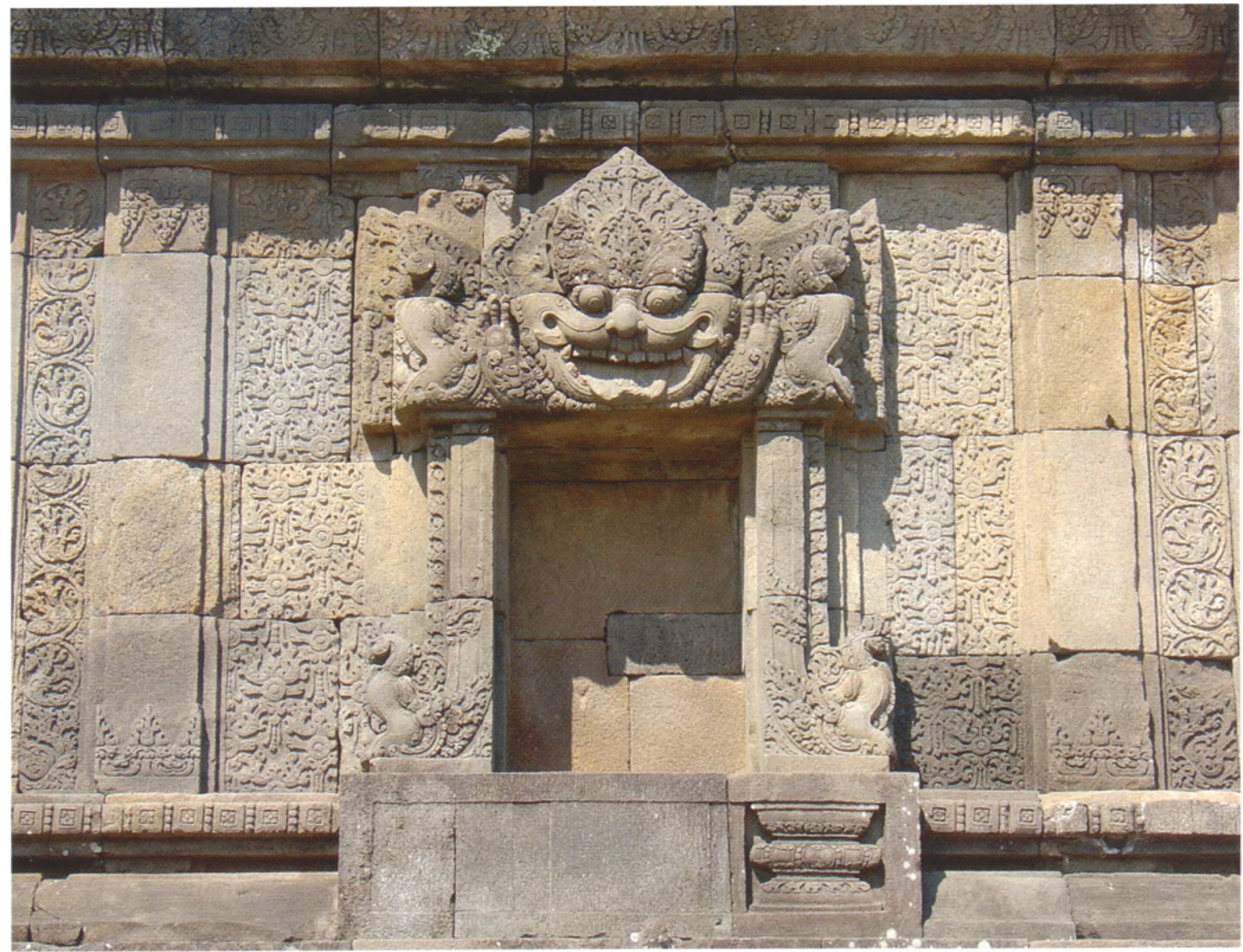

PI. 14 .

Candi Barong, west wall of the southern temple

They considered Candi Loro Jonggrang, Candi Plaosan and Candi Sojiwan to be the most recent temples, which they placed at the end of the Central Javanese period, in the tenth century. ${ }^{18}$ This conclusion was based on the interpretation of historical sources and considerations of style. After J.G. de Casparis suggested there may be a relationship between the Siwagrha inscription of $\mathrm{AD} 856$ and the Loro Jonggrang complex, ${ }^{19}$ scholars have tended to push back the date of Loro Jonggrang and stylistically related temples to the mid-ninth century or a little later, which suggests that no building activities took place during the last six decades of the Central Javanese period.

As Candi Barong was restored only quite recently, only one scholar, Jacques Dumarçay, has included it in his chronology. In his Histoire de l'architecture de Java he deals with Barong in a chapter on Hindu architecture from c.830 to the end of the $9^{\text {th }}$ century. ${ }^{20}$ He discusses it after dealing with Candi Merak which, according to him, was built after 860 . He, therefore, seems to assume that it was also built after 860 and should be grouped among the later Central Javanese temples. 
The ornamentation of Candi Barong also seems to point to a date of around 860. One of the most important pieces of evidence is the fact that the kala ornaments are represented with a lower jaw as well as an upper jaw and upraised paws on both sides of the face (Pls 11 and 14). This style signifies the last phase in the development of the kala ornament in Central Java. Such kalas are also seen at Candi Loro Jonggrang. Comparing the various dwarflike figures in Central Javanese art with those at Candi Barong and the sculpture in the Kröller-Müller Museum reveals most similarities with the figures on Candi Loro Jonggrang. Specifically, the forward-facing hands and the undulating lines between the breast and belly are characteristic of later figures (compare Pls 1, 7, 12, and 13).

\section{Conclusion}

The evidence given above points to the conclusion that the Indonesian sculpture in the Kröller-Müller Museum of a dwarf-like burden-carrying figure originates from the, probably Hindu Candi Barong in Candisari, nearby Yogyakarta. The sculpture was originally located below one of its niches, presumably that on the western wall of the southern temple, and may be dated to the third quarter of the $9^{\text {th }}$ century.

A special reason to draw attention to this sculpture is its transfer from the Kröller-Müller Sculpture Garden in Otterloo on the Hoge Veluwe, to the museum "Beelden aan Zee" in Scheveningen. It will there be shown together with about fifty tall and small Asian statues from the collection in the Rijksmuseum, forming an Asian contrast to the contemporaneous sculptures on display in the museum in Scheveningen. On show from February 26, 2008 until 1 March 2009.

\section{References}

'Candi Barong yang manakjubkan', Banjarmasin Post, 21 Agustus 2003.

A.J. Bernet Kempers, Ancient Indonesian art, Amsterdam, 1959.

J.G. de Casparis, Selected inscriptions from the $7^{\text {th }}$ to the $9^{\text {th }}$ century A.D., Bandung, 1956.

V. Degroot, Candi, space and landscape: distribution, orientation, and spatial organization of Central Javanese temple remains, $\mathrm{PhD}$ thesis Leiden, Forthc.

J. Dumarçay, Histoire de l'architecture de Java. Paris, 1993. (Publications de l'École Française d'Extrême-Orient, Mémoires Archéologiques 19).

T. van Erp, Beschrijving van Barabudur, deel 2: bouwkundige beschrijving, 's-Gravenhage, 1931. (Archaeologisch Onderzoek in Nederlandsch-Indië 3)

N.J. Krom, Inleiding tot de Hindoe-Javaansche kunst, 's-Gravenhage, 1923. 3 vols. ( $2^{\text {nd }}$ rev. ed.)

Laporan tri wulan III pra pemugaran Candi Barong tahun anggaran 1984/1985. Suaka Peninggalan Sejarah dan Purbakala Daerah Istimewa Yogyakarta.

Laporan pemugaran Candi Barong bulan Mei 1990, bulan Oktober 1990. Proyek Pelestarian/Pemanfaatan Peninggalan Sejarah dan Purbakala DIY di Bogem.

G. Liebert, Iconographic dictionary of the Indian religions: Hinduism, Buddhism, Jainism. Leiden: 1976. (Studies in South Asian culture 5).

E.M. Raven, 'Naras and kimnaras in a rocky landscape', in: Claudine Bautze-Picron (ed.), Makaranda: essays in honour of Dr. James C. Harle, Delhi, 1990, pp. 67-78. (Sri Garib Dass Oriental Series 105).

J.W. IJzerman, Beschrijving der oudheden nabij de grens der residentie's Soerakarta en Djogdjakarta. Batavia [etc.], 1891. 


\section{Notes}

1. I am grateful to Pauline Lunsingh Scheurleer for suggesting me to write this article and providing me with the relevant documentation kept in the Kröller-Müller Museum (photograph, caption, copy of the inventory of the auction where the sculpture was bought). I wish to thank Petry Kievit-Tyson for correcting my English.

2. Helene Kröller-Müller accurately saved the information of the inventory.

3. In the first decennia of the 20th century it was quite common to collect non-western art besides western art. For example Rijksmuseum, Gemeentemuseum The Hague. Also dealers like Kunstzalen Vecht, Van Lier and Kleikamp.

4. Information from the website of the Museum (www.kmm.nl).

5. Information from Pauline Lunsingh Scheurleer.

6. Van Erp 1931, pp. 372-74.

7. For instance Krom 1923, Vol. I, p. 258, 469.

8. Liebert 1976, p. 88.

9. See Raven 1990.

10. Two temples are known by name of Lumbung. The one in the district of Magelang shows dwarf-like figures in ornamental panels on its base.

11. Krom 1923, Vol. I, p. 246.

12. Miserable piles of rubble, demolished by a degenerated offspring that could not value the eminence of its forebears.

13. JJzerman 1891, p.114.

14. Laporan 1984/1985, Laporan 1990.

15. Most often the northern temple is called Candi I, and the southern one Candi II (for instance Laporan 1990). Sometimes, however, it is the other way round: the southern temple is called Candi I and the northern one Candi II (Laporan 1984/1985).

16. Degroot forthcoming: appendix, under Barong.

17. Degroot forthcoming: appendix, under Barong.

18. Bernet Kempers 1959, p. 59; Krom 1923, vol. I, p. 441; vol. II, pp. 3-4.

19. De Casparis 1956, pp. 309-311.

20. Dumarçay 1993, p. 80.

\section{Plates}

Pl. 1: $44 \times 62 \times 32 \mathrm{~cm}$. Courtesy Kröller-Müller Museum, Otterlo.

Pls. 2-14: Photographs by Marijke Klokke, taken in 2004 and 2005. 